\title{
Indigenous Plants: Key Role Players in Community Horticulture Initiatives
}

\author{
S. R. Cousins ${ }^{1}$ and E. T. F. Witkowski \\ School of Animal, Plant and Environmental Sciences \\ University of the Witwatersrand, Johannesburg, South Africa
}

\section{Abstract}

Community horticulture is central to the cultivation of plants for a range of human needs. This paper synthesizes available information on the use of indigenous plants in communal nurseries, medicinal and food crop production, agroforestry systems, ecosystem restoration, urban greening and botanical gardens. Despite considerable use of indigenous plant species in a number of community horticulture initiatives worldwide, their utilization in urban greening, food production and ecosystem restoration is infrequent and/or inadequately documented. Hence, this review highlights the potential for using indigenous plants to solve problems relating to food security, livelihood strategies, conservation of useful plants, ecosystem degradation, and biodiversity conservation in urban areas. While community horticulture programs pose potential challenges, it is important to acknowledge their many profound and all-encompassing benefits, especially with their increasingly important societal and environmental roles in light of rapid population growth and urbanization, large-scale environmental degradation, and global climate change.

Keywords: agroforestry, biodiversity conservation, food crops, medicinal plants, restoration, urban greening

\section{Introduction}

Modern horticulture is a blend of the science, art, technology, and business involved in intensive plant cultivation for human use (Hynes \& Howe, 2002; Relf, 1992). An expert horticulturist transcends the image of a "professional gardener" and requires a unique set of skills derived from several fundamental scientific fields such as soil technology, ecology, principles of plant breeding, and botany, with special emphasis on plant physiology and plant pathology (Stuart Gager, 1919). Furthermore, the realm of the horticulturist also encompasses the all-important social sciences such as education, commerce, and healthcare, which significantly enhance horticulture's contribution to society. In this sociological context, horticultural activities result in the enrichment of

1 Corresponding author: steevyc@gmail.com. 
communities, income generation, improvement of community health and the integration of "the garden" into the breadth of modern civilization (Botha et al., 2007a; Relf, 1992).

If the complex discipline that is horticulture were to be unraveled further, one of the key components that would emerge is community horticulture $(\mathrm{CH})$. Under this umbrella is an assortment of horticultural activities undertaken in community settings, the scope of which can be remarkably diverse, including community orchards, shared allotments, school gardens, community composting projects, and community nurseries (e.g., Botha et al., 2007a; Chalker-Scott \& Collman, 2006; Irvine et al., 1999). CH projects commonly focus on the cultivation of useful, but often non-native, food and medicinal crops, and the role of indigenous plant (IP) species in these initiatives is sometimes under-recognized. As populations grow, and consequent urbanization and the conversion of natural ecosystems to croplands increase, the role of IPs in $\mathrm{CH}$ endeavors in curtailing the negative impacts of these activities on biodiversity will become increasingly important. Furthermore, the use of hardy IP species adapted to local conditions may also become central to food security as climate change leads to the increased occurrence of extreme climatic events.

While there is considerable use of IP species in a number of $\mathrm{CH}$ initiatives worldwide, especially for agroforestry and the production of food and traditional medicine, the use of IPs in other spheres such as urban greening and ecosystem restoration is less well documented. Furthermore, a synthesis of the research and projects on the practical application of IPs in the field of $\mathrm{CH}$ is lacking. Hence, this paper provides an overview of the major sectors within $\mathrm{CH}$ where IPs play important roles, and highlights opportunities for further research and subsequent project involvement.

\section{The importance of community horticulture to local communities}

Half of the world's seven billion people reside in cities, and almost two out of three people will be living in urban areas by 2030 (Hynes \& Howe, 2002). Thus, most people's experience, environmental literacy, claims to natural assets, and knowledge and appreciation of nature in the twenty-first century will be shaped and, for most, bounded by the natural, social and built environments of the urban settlements in which they live (ibid.). At first glance, a community garden might appear to be a minor, merely local experience of nature that could be more genuinely sought in wild and remote places. However, gardens represent "the middle ground between the wilderness and the lawn," and may facilitate the forging of a new urban environmental ethic, and provide help in situations 
where "the wilderness ethic is silent or unhelpful" (Pollan, 1992). Furthermore, gardens provide alternatives in cases where the experience of wilderness areas is unaffordable, remote, or inaccessible (Hynes \& Howe, 2002).

The relevance of $\mathrm{CH}$ programs to local communities is vast and multifaceted, and benefits include income generation, food security, improved urban environmental conditions, ecosystem restoration, social upliftment, crime reduction, and conservation of threatened and commercially valuable species (Botha et al., 2007a; Chalker-Scott \& Collman, 2006; Hynes \& Howe, 2002; McKinney, 2002; Waliczek et al., 1996). Gardens also have the profound ability to ameliorate peoples' quality-of-life needs on the higher levels of esteem and self-actualization (Waliczek et al., 1996). Community gardens assist in creating and sustaining relationships between city residents and the soil, and can engender an ethic of urban environmental awareness that neither parks nor wilderness areas - which release and free people from the city - can do (Hynes \& Howe, 2002).

\section{Key uses of indigenous plants in community horticulture programs}

Many $\mathrm{CH}$ initiatives have focused on the production of primarily non-native food crops in urban areas, such as the highly successful Matalahib barrio community garden in Quenzon City, Manila, the Philippines; and several urban community gardens in Kenya, Australia, the United States, United Kingdom, Spain, and elsewhere in Europe (Buckingham, 2003; Domene \& Saurí, 2007; Guitart et al., 2014; Irvine et al., 1999; Saldivar-Tanaka \& Krasny, 2004). However, others have demonstrated the importance of cultivating IPs for urban greening (McKinney, 2002), conservation (e.g., Böhringer et al., 2003; McKinney, 2002), ecosystem restoration (e.g., Dreesen \& Harrington, 1997; Markham et al., 2011; Weiersbye \& Witkowski, 2002), and education (e.g., Tunnicliffe, 2001). The cultivation of native medicinal plants to supply traditional healers and curtail the exploitation of wild medicinal species has also been widely advocated for over half a century (e.g., Botha et al., 2007a; Dzerefos \& Witkowski, 2001; Gerstner, 1946; Hamilton, 2004; Jäger \& Van Staden, 2000; Mander et al., 1996; Ndawonde et al., 2007). There is also great potential for indigenous food crops (e.g., Xaba, 2007) to be grown in community nurseries to supplement mainstream food sources, especially in areas where the cultivation of conventional food crops is difficult due to unsuitable local environmental conditions.

\section{Communal nurseries}

IP domestication can aid the conservation of wild resources by enrichment planting in forest areas, smallholder cultivation, and commercial or community 
plantations (FAO, 1995; Wickens, 1991). Outreach nurseries (sensu Botha et al., 2006, 2007a, 2007b), which are established in conjunction with local stakeholders, are favored conservation and social forestry tools globally, but, as with many integrated conservation and development plans, they do not always produce anticipated results (Botha et al., 2006). Furthermore, domestication and cultivation do not necessarily substitute conservation of genetic diversity, and if no provision is made for the preservation of genetic variation in wild sources, domestication is often followed by decline or disappearance of wild populations (Nair \& Merry, 1995). Thus, the advantages and disadvantages of community cultivation projects, including the needs of local communities, and the long-term commitment and economic capital required, must be evaluated to determine the viability of such projects.

Botha et al. (2007a) demonstrated the important social benefits of 65 outreach community nursery projects established among a wide range of ethnic groups in South Africa. The initiatives had the primary objective of growing IPs for income generation in local communities, yet several additional benefits to these communities were also gained. Although the projects had mixed success, with some nurseries breaking even and/or later generating profits, and others declining to a state of collapse, participants acquired skills such as environmental education, and business and health care training, regardless of the success or failure of the respective projects. Furthermore, projects that succeeded resulted in the development of parks; the securing of a resource base of medicinal plants; improved food security; and the promotion of participants' psychological wellbeing through increased self-confidence, sense of purpose, pride and ownership, and personal satisfaction (ibid.). Well-managed communal nurseries could focus on the production of IPs for a range of activities, such as medicinal and food plant cultivation, ecosystem restoration, and urban greening.

\section{Cultivation of medicinal plants}

Hundreds of millions of people, mostly in developing countries, derive a significant part of their subsistence needs and income from gathered plant and animal products (Iqbal, 1993). Harvesting of high-value products such as plants for food and medicines also continues in developed countries for cultural and economic reasons, and demand for wild species is increasing with growth in human needs, numbers, and commercial trade (Schippmann et al., 2003). In southern Africa, traditional medicine is an important healthcare component, and most drugs are prepared from plants, almost all of which are wild-collected (Jäger \& Van Staden, 2000). In South Africa, the trend toward increased commercialization of medicinal plants has resulted in overharvesting and, in some cases, near extinction of certain valued IP species (Williams et al., 2000). Hence, Jäger and Van Staden (2000) argued that a new strategy for developing medicinal plants as commercial crops is needed, particularly in South Africa, 
but also elsewhere. This approach is not new, however, and was identified over 60 years ago by Gerstner (1946). Indeed, a number of agencies are recommending that wild species be introduced to cultivation systems and, given the demand for a continuous and uniform supply of medicinal plants and the accelerating depletion of wild resources, increasing the number of indigenous medicinal plant species in cultivation would be an important strategy for meeting market demands and conservation objectives (Uniyal et al., 2000). In South Africa, extensive research has been undertaken over the last two to three decades on the mass production of useful IPs (Mander et al., 1996). Besides the potential for cultivation of medicinal plants as crops to reduce the need for wild collection, it also facilitates the development of improved strains, for instance, varieties with enhanced plant vigor and efficacy (Ndawonde et al., 2007).

Ex situ conservation is not always sharply separated from in situ conservation, and there are intermediates between the purest forms of both types (Hamilton, 2004). Circa situ conservation refers to a range of practices commonly associated with more traditional and biodiversity-rich agricultural systems (ibid.). This integrated approach includes deliberately encouraging the retention of certain "wild" plant species, which could include indigenous medicinal plants in "natural" habitats and other valued "wild" plants when land is cleared for agriculture, or when croplands are weeded. It also encompasses the growing of valued plants in home gardens, and the selection and storage of seed at the household level for later replanting (ibid.). In a survey of the medicinal plants sold by traders in the traditional medicine markets of Zululand, KwaZulu-Natal, South Africa, Ndawonde et al. (2007) identified 32 species as important candidates for ex situ cultivation initiatives. As part of a broader, holistic conservation approach, including trade monitoring and legislation, the establishment of communal gardens by plant traders was proposed to alleviate pressure on wild populations and increase the availability of rare and threatened species (ibid.). This recommendation is supported by Kowalski and van Staden (2001), who indicated that the propagation of heavily exploited and endangered trees such as stinkwood (Ocotea bullata) and pepper bark (Warburgia salutaris) has facilitated conservation and reforestation. Warburgia salutaris is widely regarded as the most highly prized medicinal plant in southern Africa, and is an excellent example of how the improvement of conservation and livelihoods can be achieved by marrying in situ and ex situ conservation through circa situ means (Botha et al., 2004; Cunningham, 2001). This species has been successfully reintroduced from nurseries in South Africa to Zimbabwe, where it had gone nationally extinct. However, reintroduction was not back into its natural forest habitat, from which it would probably again soon disappear; rather, rooted cuttings were distributed for the home gardens of local farmers, all of whom knew and valued the species, and were prepared to safeguard the young plants for future use (Cunningham, 2001). 
Despite the many advantages of medicinal plant cultivation, in certain circumstances it can be impractical. Biological and ecological requirements can be difficult to meet or circumvent, for example, slow growth rates, interactions with pollinators and other species, low germination rates, and susceptibility to pests (Loundou, 2008). Cycads, for example, which are used for traditional medicine in South Africa (Cousins et al., 2011, 2012), have such slow growth rates that cultivation to supply local demand is simply not an option. Medicinal plant production through cultivation can reduce pressure on wild populations, but it may also lead to loss of genetic diversity and loss of incentives to conserve wild populations (Schippmann et al., 2003). Furthermore, cultivated plants are sometimes considered qualitatively inferior when compared with wild-gathered specimens, largely for cultural reasons, but also due to perceived differences in efficacy (ibid.). In Botswana, for example, traditional medicinal practitioners claimed that cultivated plants were unacceptable, as such material lacked the power of wild-collected plants (Cunningham, 1994). Scientific studies partly support this argument, as the medicinal properties in plants are primarily due to the presence of secondary metabolites which the plants need in their natural environments. These compounds are required under particular conditions of stress and competition, and may not be expressed as strongly in the fast-growing cultivated stocks grown under ideal monoculture conditions (Schippmann et al., 2003). Notwithstanding, it is also clear that certain values in plants can be deliberately enhanced under controlled conditions of cultivation (Uniyal et al., 2000), which may include the potency of the active medicinal compounds. Working with local people to determine the microhabitats in which medicinal plants grow in the wild may help in simulating these conditions in a nursery setting.

Owing to the sometimes significant impediments to medicinal plant cultivation, Hamilton (2004) notes that sustainable harvesting of wild stocks is often recommended as the best option for medicinal plant conservation, especially where cultivation is not possible. Wiersum et al. (2006) also advise that if medicinal plant conservation is undertaken, it should be carefully linked with social upliftment by identifying the ties between cultivation practices and livelihood conditions, the role of cultural factors in medicinal plant use and conservation, and that cultivation by local people should not be based primarily on local awareness of the loss of wild species, but on local perceptions of financially lucrative medicinal plants. Furthermore, Botha et al. (2007b) caution that nurseries are risky ventures, even in conducive operating environments, and before embarking on projects, organizations have a moral obligation to consider the potential impacts of projects on local stakeholders. These responsibilities include assessments of project viability as well as the organizations' own willingness and ability to commit to the extensive time frames and resources that are inevitably required (ibid.). 


\section{Agroforestry}

Many projects involving the cultivation and use of IPs by local communities infiltrate several spheres of influence, and agroforestry initiatives are a case in point. Agroforestry systems represent a major form of small-scale tree planting, where trees are grown in specific combinations with agricultural crops and/ or livestock for a range of objectives (Long \& Ramachandran Nair, 1999). Agroforestry schemes take advantage of tree-crop interactions, and thereby enhance crop production, diversify farm output, stabilize or improve soils, and ameliorate harsh environmental conditions (ibid.). Community forestry, on the other hand, relates to tree planting undertaken by a community on common land, and is based on peoples' direct participation-either by propagating trees themselves or by processing tree products locally (ibid.). Compared to the cultivation of exotic tree species, indigenous forest trees play an important role in meeting the needs of local communities in terms of timber, fuelwood, food, and traditional medicine provision, but may also contribute to ecosystem restoration (e.g., Aumeeruddy-Thomas et al., 2004; Cunningham et al., 2002; Saxena et al., 2001), and in situ conservation, albeit in an anthropogenically modified context (Koh \& Gardner, 2010). The sheer extent to which humans have dominated the biosphere necessitates the integration of conservation efforts with human activities, such as urban and rural development (ibid.).

While the majority of studies show that despite the invariable loss of some species from the conversion of native habitat for agroforestry use, a large proportion of the original fauna and flora is maintained, as compared to more intensified agricultural land uses (Ranganathan et al., 2008). Notwithstanding, agroforestry systems are dominated by only one or two commercially important, usually exotic species (e.g., Eucalyptus and Pinus), which are planted mainly in woodlots near farms, along roads, around villages, and as riparian buffers (Long \& Ramachandran Nair, 1999). Species diversity is an essential feature of agroforestry systems; in addition to providing fuelwood and timber, a mix of indigenous tree species provide a range of non-timber forest products, and also assist in ecosystem restoration, protection of water quality, and enhancement of local faunal diversity, and therefore should be included in agroforestry initiatives (ibid.).

In the Himalayas, deforestation is a serious threat to biodiversity, and is generally attributed to demographic pressure, which results in demand for land for agriculture and the use of remaining forest to meet growing needs for fodder, fuelwood and timber (Aumeeruddy-Thomas et al., 2004). The Ayubia Ethnobotany Project at the Ayubia National Park in northern Pakistan was therefore instituted to provide recommendations for improvement of fodder and fuelwood management systems, as well as to implement activities to contribute toward the sustainability of plant resource use in the park. One component of the 
project involved engaging with local villagers to establish 172 nurseries of fastgrowing multipurpose tree species to increase fodder and fuelwood production, and train people in nursery-raising techniques. Tree seedlings were propagated in household and community nurseries for planting on privately owned land and for enrichment of natural forested areas to promote indigenous species conservation (ibid.). Although the project initially achieved poor results, after adapting and improving the approach, approximately 5,300 trees have been planted with community participation, resulting in capacity building, as well as diminished pressure on wild stocks and supplementation thereof (ibid.).

Another case where cultivation of indigenous trees by communities was successful is the Prunus africana project in Cameroon. Wild populations of this Afromontane forest tree (known as the African cherry) were the sole source of medicinal bark and bark extract, and bark products from Africa and Madagascar exported to Europe constituted the largest volume of any African medicinal plant in international trade (Cunningham et al., 2002). This exploitation has caused serious damage to wild populations, especially in key conservation areas in Madagascar and Cameroon (ibid.). In an effort to combat the depletion of wild P. africana populations, the Kilum Mountain Forestry Project has been helping farmers since 1989 to establish nurseries and plant $P$. africana and other IP species on their farms in the Oku area of the Bui Division, Cameroon. In 1994, there were 35 functional group nurseries, where group members shared seedlings, planting most on their farms and selling some to other farmers and to the project, to be used for forest enrichment planting (ibid.). In total, the groups produced approximately 14,000 P. africana seedlings in 1994, and the project purchased 5,348 seedlings for forest enrichment; farmers planted most of the rest on their own farms (ibid.).

These projects, the aforementioned $W$. salutaris cultivation initiative, and many others (see Lapido et al., 1996; Munyanziza, 1996; Ngwira, 1996; Ohlendorf, 1996; Shah \& Kalakoti, 1996), clearly illustrate the potential of useful plant domestication. Moreover, the results of Aumeeruddy-Thomas et al. (2004) and Cunningham et al. (2002) show how using IPs in $\mathrm{CH}$ can have powerful, positive impacts not only on species conservation and ecosystem restoration, but on the socio-economics of the associated local communities as well. Nonetheless, it is important that local people are properly educated about the benefits of indigenous agroforestry in order for them to recognize its value, and promote their involvement and investment in such projects. It is also vital that the IPs selected for cultivation are suitably adapted to local conditions (ideally indigenous to the specific area in question), and offer goods and services that the community and surrounding ecosystems will derive significant gain from. 


\section{Food security}

Conventional (mostly non-native) food crops have long enjoyed significant popularity in $\mathrm{CH}$ (Hynes \& Howe, 2002), but there is also increasing emphasis on the cultivation of indigenous food crops. Shifts from the use of traditional foodstuffs (usually a wide variety thereof, and of significant nutritional value) to more conventional (westernized), appealing, but often less nutritious, foods has been witnessed in many cultural groups worldwide, frequently with negative health consequences (Kuhnlein \& Receveur, 1996). Decades of official food security policies globally completely ignored the importance of most foodstuffs provided by wild plant species, particularly those harvested from impoverished and agriculturally marginal lands (Dovie et al., 2007). Disregard for, and under-utilization of, indigenous food crops is further exacerbated by the lack of knowledge on the domestication and cultivation of these species, especially in African savannas (ibid.). Moreover, governments and policymakers often ignore the contribution made by (indigenous) trees to local communities, and consequently focus resources on cash crops and livestock (Paumgarten et al., 2005). Okafor (1980), for example, noted that most of the important staple foods in the humid tropics of Nigeria were plants such as cassava, maize, and potato introduced from tropical America or Asia. These crops are only seasonally available, and their utilization is associated with storage problems (ibid.). By contrast, many indigenous woody plants - cultivated, protected, or wild-are good sources of inexpensive plant protein and other essential nutrients, and are obtainable at times of the year when annual staples are unavailable or difficult to store (ibid.). West African compound farms, for example, are dominated by indigenous trees that produce leafy vegetables (Pterocarpus species), fruit for cooking (Dacroydes edulis), and condiments (Pentaclethra macrophylla), thereby adding a significant contribution to the diets of people in local communities (ibid.).

Indigenous species may also serve important complementary purposes, such as soil erosion control, provision of mulch materials, windbreaks, structural materials, timber, fuelwood, medicines, and items for religious purposes (Luoga et al., 2000; Okafor, 1980). Hence, the wide range of uses of indigenous food crops, in addition to human consumption, give them superlative value as potential alternatives to conventional (non-native) food crops for cultivation in $\mathrm{CH}$. In addition, the cultivation of hardy and adaptable indigenous crop species will likely become increasingly important as food security is jeopardized by a changing climate. Trees in particular provide an array of goods and services to households, and when incorporated into peoples' livelihood strategies (e.g., cultivation through home-based and $\mathrm{CH}$ initiatives) may help reduce their vulnerability to adversity (Paumgarten et al., 2005). 
Since 2007, in an effort to promote the cultivation of indigenous food plants in South Africa, a series of articles have appeared in the popular botanical journal Veld \& Flora, which provide information on the uses and propagation techniques of several edible and medicinal plant species indigenous to South Africa (e.g., Xaba, 2007). The edible species described are mostly easy to cultivate, adapted to a range of environmental conditions, disease resistant, and produce nutritious fruit, vegetables, leaves, or tubers for human consumption. Increased awareness and encouragement of the use of indigenous species in both rural and urban $\mathrm{CH}$ projects is vital if we are to move from conventional crops to more appropriate indigenous ones in order to provide food security in a context of global change.

\section{Rural food security}

Numerous resource-poor households in rural areas of most countries are directly dependent on IP resources as an integral part of their livelihoods (Dovie et al., 2007 and citations therein). On a management continuum from truly wild to cultivated, wild food plants are not only an essential source of nutrients, but also provide seasonal dietary diversity to many communities worldwide (CruzGarcia \& Howard, 2013). While many cultural groups residing in rural areas have a rich indigenous knowledge about wild food sources, their cultivation and preparation, this knowledge is being eroded as the consumption of exotic species and ready-made foodstuffs have become symbols of modernity or wealth (Kuhnlein \& Receveur, 1996). Conserving indigenous knowledge is thus important for continued use of wild food resources (Dweba \& Mearns, 2011), and negative attitudes toward their use can be reversed through education programs (e.g., Cruz-Garcia \& Howard, 2013). While indigenous food plants are mostly wild-harvested, Legwaila et al. (2011) argue that domestication could be used as a strategy to improve food security and cash income for people living in rural areas, and as a means of carbon sequestration for climate change mitigation. Cultivation of indigenous food plants could also reduce pressure on wild populations and, if irrigated, could ensure availability in times of drought in the case of annual herbs.

Farmers in southern Africa are known to retain and protect indigenous fruit trees on their lands, since many rural households rely on these trees as sources of income and subsistence in the Southern Africa Development Community (SADC) (Akinnifesi et al., 2006; Dovie et al., 2007). However, until recently, there has been only a modest effort to cultivate, improve and add value to these fruits. Since 1989, the International Centre for Research in Agroforestry (now the World Agroforestry Centre) initiated research and development work on over 20 priority indigenous fruit tree species in five SADC countries, aimed at improving income generation in rural communities (Akinnifesi et al., 2006). A participatory approach was employed in all stages of domestication, product development, and commercialization. Country-specific priority species were 
identified, and have since become the focus of a regional tree domestication program (ibid.). Notably, on the list of priority species is the marula (Sclerocarya birrea subsp. caffra), which is frequently maintained in homestead plots and arable fields in an agroforestry situation in southern Africa (Shackleton, 2002). It is regarded as a keystone species across its distribution, and is used by rural populations in most countries in which it is found (Helm et al., 2011; Shackleton, 2002). Its indispensability to local communities is ascribed to its multiple uses: the fruits are eaten fresh or fermented to make beer, the kernels are eaten or the oil extracted, and the leaves are browsed by livestock and have medicinal uses, as does the bark (Shackleton, 2002).

Another keystone indigenous tree species that is central to the livelihoods of people in rural African communities is the baobab (Adansonia digitata). Like marulas, baobabs have a wide range of uses, especially for food, fiber, and medicine (Venter \& Witkowski, 2011, 2013). (Buchmann et al. (2010) reported over 300 uses of all parts of the plant altogether.) Where baobab products are sold in informal markets, they form a key source of income for thousands of rural people. Cash generated from the sale of baobab fruit helps alleviate poverty, improves livelihoods, and allows participation of marginalized people in a growing cash economy (Venter \& Witkowski, 2011). Fruit is collected from trees in fields, villages, and surrounding communal land by locals, and processed in situ to supply fruit pulp and oil from the seeds to a large and growing export market (ibid.). Cultivation (possibly in a communal horticultural setting) is another way to increase benefits, and suitable sites could be found in southern Africa, which could follow the lead of West African initiatives in domestication and cultivation (ibid.).

\section{Urban food security}

Urban community food gardens are common in certain parts of the world, especially in Europe and the United States (Corrigan, 2011). The community food security movement was initiated in the latter in an attempt to overcome an unequal distribution of food by localizing food production (ibid.). However, despite their prevalence, a broad literature search specifically on indigenous crop cultivation in urban community gardens yields very few studies. Hence, there appears to be a paucity of research in this area, except for the comprehensive work of Shackleton et al. (2009) on African indigenous vegetables in urban agriculture. It is unclear how many community gardens incorporate the cultivation of IPs in their plantings, what kind of IPs they use, and for what reasons.

A study on the vegetable gardens of the Barcelona Metropolitan Region by Domene and Saurí (2007) showed that a large variety of conventional crops are grown (e.g., potatoes, tomatoes, lettuces), but no mention was made of 
using IPs. Guitart et al. (2014) indicated that only 12 percent of the 234 plants grown in 23 school gardens in the cities of Brisbane and Gold Coast in Australia were indigenous. Saldivar-Tanaka and Krasny (2004) showed that a mixture of indigenous and exotic fruit and vegetables are cultivated in Latino New York City gardens, but the relative proportions were unclear. It may be that in urban areas the seed and other propagative material of commonly used exotic fruit and vegetables is more easily available than that of less commonly grown indigenous crops, whereas in rural areas people have direct access to the seeds of indigenous species that grow in their surroundings. Rural people are also likely to have more knowledge about the food plants that grow in their surroundings and are therefore more inclined to incorporate them into their gardens, while urban dwellers are more accustomed to non-indigenous conventional fruit and vegetables, which adequately satisfy their dietary requirements.

Shackleton et al. (2009) note that in many sub-Saharan African cities, urban and peri-urban agriculture supplies substantial amounts of the vegetables consumed, and could be potentially transformed into a significant source of indigenous vegetables for urban areas. In order for this to happen, research will need to be undertaken to determine which indigenous vegetables are already being cultivated in this context, the extent to which they are cultivated, and the reasons why these specific vegetables are grown (ibid.). Formulating a strategy for increasing their production in urban and peri-urban areas (including $\mathrm{CH}$ initiatives) will necessitate a comprehensive understanding of their agronomy, cultural acceptability, and marketing structures (ibid.).

Urban community gardens are constrained by access to land (de Neergaard et al., 2009). In the United States, for example, the longevity and permanence of community gardens is delicate and insecure given that they are often located on land that continues to be classified as "open" or "vacant" because it implies an ongoing trajectory toward development of "higher and better use" than gardening (see Drake \& Lawson, 2014 and citations therein). In response to these land tenure challenges, community gardening often takes place on school grounds or similar semi-publicly owned land (de Neergaard et al., 2009). In some cases, gardening activities are integrated with the school kitchen and teaching activities (ibid.). The use of IPs in such settings could provide substantial enhancement of children's dietary requirements owing to the high nutrient status of many traditional/indigenous food plants. Furthermore, by integrating the gardening activities into school curriculums, learners would gain knowledge on their indigenous flora and develop an appreciation thereof. Notwithstanding, while the use of school grounds for community gardens provides a feasible alternative to vacant lots, city councils should be persuaded to rezone community gardens currently situated in "vacant lots" as permanent sites for this purpose. City planners must be convinced of the crucial role 
community gardens play in food production, building social capital, and income generation, thereby addressing urgent concerns relating to food security, urban sustainability, and neighborhood revitalization (Drake \& Lawson, 2014).

\section{Urban greening}

Escalating urbanization and conversion of land for agriculture, forestry, and industry is rapidly depleting natural areas worldwide (McKinney, 2002; Pickett \& Cadenasso, 2008), and it is therefore vital that a concerted effort is made to safeguard IPs and their associated wildlife across urban areas (Joffe, 2005). Among the many human activities that result in habitat loss, urban development produces some of the greatest local extinction rates, and commonly eliminates the vast majority of native species (McKinney, 2002). Jim and Liu (2001) emphasize that sound ecological planning in cities, such as the designation of interconnected green belts, is extremely important, especially in new, rapidly urbanizing countries such as China. In this context, effective management of the large amount of residential vegetation in urban areas in ways that promote native fauna and flora could make a significant contribution to conservation (McKinney, 2002). Indeed, urban green spaces are becoming an increasingly important refuge for native biodiversity (Goddard et al., 2010), and cultivation of IP species may benefit not only local IP populations, but also native animal populations (McKinney, 2002). For example, indigenous bird and insect species richness in Australia and North America tends to be positively correlated with the prevalence and species diversity of indigenous vegetation. Landscaping golf courses with IPs can also benefit many local native bird species (ibid.). In contrast to small disparate niches between buildings, spatially contiguous green spaces, where natural or semi-natural vegetation is preserved, furnish opportunities for spontaneous indigenous vegetation expansion, thereby creating natural bastions of biodiversity within cities (Jim \& Liu, 2001).

Urban green spaces provide a range of important ecosystem services that contribute to enhanced quality of life, including aesthetic amenities, diminution of energy use for cooling, increased carbon sequestration, filtration and attenuation of storm water runoff, shade provision and associated energy cost reductions, and promotion of neighborhood social capital (Bolund \& Hunhammar, 1999; Parkin et al., 2006; Pickett \& Cadenasso, 2008; Troy et al., 2007; Ward et al., 2010). Planting (indigenous) plants in urban settings may also help curtail air and soil pollution and the "heat island" effect, boost average annual rainfall, reduce soil erosion and compaction, reduce the need for routine application of pesticides, and encourage the occupation of green spaces by indigenous fauna (McKinney, 2002). As such, IPs have excellent potential for planting in suburban gardens, parks, on traffic islands along highways, along boulevards, and in industrial areas (Pienaar, 1994), where they can significantly enhance otherwise harsh human-made environments. By increased focus on 
urban ecological dynamics, a powerful collaborative effort involving ecologists, urban planners, landscapers, and architects can significantly enhance these environmental goods and services throughout the cities and towns in which they work (Pickett \& Cadenasso, 2008). The role of green spaces is especially salient in lower income central city areas, where residents tend to gravitate disproportionately toward vegetated areas for activities occurring in outdoor common spaces (Troy et al., 2007). There is therefore vast potential for these impoverished communities to engage in $\mathrm{CH}$ programs to both enhance the local cityscape and encourage social upliftment.

As an example of the dramatic effects urban greening can have, the city of Johannesburg in South Africa, with its estimated 10 million trees, is considered one of the world's largest urban forests, but arose from an otherwise predominantly treeless grassland (Foster, 2009). The forest resulted from early plantations of non-native trees such as Eucalyptus species intended to supply pit props for the gold mines, but also to make the city livable for its early white residents (ibid.), and as the suburbs expanded, the tree-planting ethic in private gardens and on street pavements continued. In recent years, the Greater Johannesburg Metropolitan Council has ardently planted even more trees - mostly indigenous species - in the historically sparsely vegetated southern suburbs, with a major focus on Soweto (ibid.). New and existing planted trees provide substantial ecosystem services to the city, which the former natural grassland would be unable to offer. The trees being planted are mostly cultivated by Johannesburg City Parks, and while providing much employment through the greening of disadvantaged areas of the city, $\mathrm{CH}$ proponents could potentially be significant stakeholders in this, and other similar IP urban greening initiatives elsewhere. Notwithstanding, the planting of trees in a grassland biome has also presented conservation issues surrounding the protection of grassland species, including many perennial forbs and geophytes in addition to grasses (Grobler et al., 2006). Hence, tree planting should be done only in degraded areas or wastelands, pavements, and parklands where native grassland species have already been eliminated.

The cost reductions of maintaining indigenous urban green areas is a possible drawcard for investment in greening initiatives, since IPs are adapted to local conditions, and therefore require less maintenance (e.g., watering, fertilizing and pesticide application) than exotic plants. Hence, $\mathrm{CH}$ initiatives, representing a collective effort of people interested in and concerned about conservation in their towns and cities, can use IP species to add significant value to conservation in urban areas, while simultaneously delivering an array of social benefits to city residents. A potential financial spin-off of $\mathrm{CH}$ programs focused on IP cultivation is that suburbs of low economic status can create opportunities for income generation through the sale of plant products such as fruits, medicine, 
dyes, and fuelwood (Parkin et al., 2006). However, Breuste (2004) cautions that two important subjects require consideration when implementing any IP urban greening scheme: first, the nature of the original biomes in which the urban region is situated, and second, the cultural aspect of acceptance of various natural systems. Furthermore, the feasibility of reducing the human impact on urban open spaces by reintroducing indigenous vegetation must be determined, as well as the circumstances under which this will work (ibid.).

Despite the considerable volume of scientific knowledge on IPs in urban and periurban areas, its use is fairly limited (Breuste, 2004). On a broader scale, in spite of worldwide rapid urban sprawl, urban ecology has received little attention from conservation biologists, largely due to the traditional focus of conservation research on "natural ecosystems" such as old-growth forests (Koh \& Gardner, 2010; Pickett \& Cadenasso, 2008). Moreover, utilization of indigenous vegetation in the urban landscape is still problematic in decision-making and planning (Breuste, 2004). On the one hand, there are many activities in cities and towns aimed at providing more green spaces, while on the other, there is escalating destruction of indigenous vegetation, not only for building purposes, but also partly due to maintenance costs of urban open spaces and a growing number of recreational activities requiring cleared land (ibid.). Although urban landscapes represent the worst-case scenario in ecosystem management, society is faced with the ever-increasing task of conserving biodiversity in such "unnatural" environments (Koh \& Gardner, 2010). It is therefore likely that the use of IPs in $\mathrm{CH}$ and other urban greening initiatives will become an increasingly important component of biodiversity conservation in general.

The potentialities of advocating the planting of IPs by, for example, garden clubs in suburban areas, as another form of $\mathrm{CH}$, should not be underestimated. Nonetheless, human acceptance of the sound ecological principles of indigenous urban greening is still an uncertain factor requiring investigation and will, in the long term, be improved by education and evaluated under different cultural and social aspects (Breuste, 2004). Jim and Liu (2001) note that new green spaces in Guangzhou City, China, are often characterized by small, decorative flowering trees, which add considerable aesthetic value, but offer fewer ecosystem goods and services than do indigenous tree species. The rapidly expanding modern metropolis of Shenzhen, known as the "Garden City of China" boasts large swathes of attractive flowering trees and shrubs throughout the city (S. R. Cousins, personal observation). A shift toward planting a mix of decorative ornamentals and more ecologically beneficial IPs may significantly enhance biodiversity conservation and ecosystem goods and services provision in the city. While the use of IPs in urban greening initiatives may present many benefits on paper, perhaps one of the major factors that will underpin the success of such schemes in practice is the cultivation of an ethos of 
indigenous greening in children and young people, who generally show greater willingness to participate in such projects than do adults (Parkin et al., 2006). Children's awareness of the importance of IP cultivation and conservation in urban settings, such as through school greening projects, may help shape their future decisions in terms of sustainable living, and promote the implementation of future projects where their participation can help bridge "knowledge-action gaps" in the enhancement of their local communities (ibid.).

\section{Ecosystem restoration}

Cultivation of key IP species can be extremely useful for restoration of degraded ecosystems in and around cities (McKinney, 2002), in communal rangelands (e.g., King \& Stanton, 2008), and in secondary forests (Koh \& Gardner, 2010). Shimozono and Iwatsuki (1986) also emphasize the importance of the propagation of rare and threatened IP species for ex situ conservation in botanical gardens, and the subsequent use of propagated material for reintroductions into the wild to facilitate in situ conservation. Dreesen and Harrington (1997) report that restoration of disturbed lands in the southwestern United States has become a primary objective of many federal and state land management agencies, and a regulatory requirement for extractive industries. Frequently, containerized or bare-root plant materials are used for reclamation activities following severe disturbances or for reintroduction of woody IP species formerly present on poorly managed lands (ibid.).

King (2008) showed that in degraded semi-arid Kenyan rangelands, areas within a two-meter radius of indigenous Aloe secundiflora plants were positively associated with higher vegetation cover, species richness, litter cover, soil seed banks, and soil water retention compared with areas devoid of vegetation cover. Planting aloes in degraded rangelands is also known to improve the effectiveness of grass reseeding for rangeland rehabilitation (King \& Stanton, 2008). It has also been suggested that the mass propagation of spekboom (Portulacaria afra) could be critical to thicket rehabilitation in the Eastern Cape, South Africa, because it grows easily from cuttings and sequesters large quantities of carbon in both soils and biomass at the landscape scale (Powell et al., 2004). Botha et al. (2008) indicated that the transplanting of leaf-succulent species from undisturbed to rehabilitated surface mining areas in Namaqualand, South Africa, was considered a successful restoration method for the reintroduction of indigenous vegetation. Propagating these succulents in nurseries may also be a viable strategy. Cultivation of suitable IPs is also key to the successful stabilization of mine tailings (e.g., Markham et al., 2011). Weiersbye et al. (2006) highlighted the importance of IP species for restoration in a study of the floristic composition of gold and uranium tailings dams and adjoining polluted areas of deep-level mines in South Africa. Of the 376 species identified in the intensive survey, most of the species found on tailings were persisters or natural 
colonizers (53-88 percent, depending on substrate), with the majority being indigenous taxa (76 percent) (Weiersbye et al., 2006). Naturally colonizing and persisting species were primarily indigenous perennials comprising resprouting, semi-woody and woody plants, and C4 tussock grasses, which, by virtue of the relatively longer life-span of individuals and apparent tolerance to the tailings conditions, are more likely to assist in the establishment of self-sustaining cover and rehabilitation of gold tailings (ibid.). Furthermore, in an effort to ascertain the potential of these species for sustainable rehabilitation of gold mine tailings, Weiersbye and Witkowski (2002) characterized seed production, seed fate, and patterns of seed dormancy and germination for 46 of the most highly suitable species. These results have been used to develop propagation techniques and protocols for mine tailing rehabilitation initiatives. Such endeavors provide opportunities for communities to engage in $\mathrm{CH}$ projects; communities would benefit not only from employment, but also experience enhanced living conditions in the vicinity of stabilized mine tailings.

\section{Botanical gardens}

If the concept of $\mathrm{CH}$ is expanded beyond the collective effort of people in local communities cultivating plants for various environmental and socio-economic purposes, it could also encompass botanical gardens, and the vital roles they play in over 150 countries across the globe. Botanical gardens are unique public green spaces as they are so-called "shop windows of biodiversity" (Ward et al., 2010). The roles played by botanical gardens are multifaceted, and include holding of documented collections of living plants for the purposes of scientific research, conservation, display, and education (ibid.). Based on its available resources and public demand, each botanical garden identifies the strategy and directions of development of scientific and educational projects, and also identifies its particular socioecological role and positioning in the region in which it is located (Kuzevanov \& Sizykh, 2006). A key function of botanical gardens is to develop public understanding of biodiversity and conservation biology, whose foundations lie in the identification of IP specimens (Kuzevanov \& Sizykh, 2006; Tunnicliffe, 2001), an activity that is central to botanical garden visits. Through displays of broad collections of decorative and useful food and medicinal IPs, botanical gardens can play a pivotal role in stimulating visitors' ideas with regard to using IPs in home gardening, and thereby contribute to indigenous urban greening.

In addition to their vital functions as environmental education facilities, botanical gardens are also crucial for biodiversity conservation (Donaldson, 2009). In response to the increased exploitation and degradation of wild plant resources worldwide, conservationists have removed specimens of rare and threatened plant species from the wild and attempted to propagate them in the artificial, but protected environment of botanical gardens (Shimozono \& Iwatsuki, 
1986). Cycads epitomize this vital role of botanical gardens, as they are highly prized collector's items in the horticultural trade and several species have gone extinct in the wild due to over-collection (Donaldson, 2003), now surviving only in private collections and botanical gardens. Other conservation initiatives include the establishment of gene banks for IPs, including living collections, seed banks, and plant tissue cultures; the development of herbaria and research on plant systematics; and research on the restoration of degraded habitats and subsequent reintroduction of plant species to these areas (Kuzevanov \& Sizykh, 2006). Botanical gardens also involve local communities in environmental conservation and decision-making with regard to plant protection (ibid.). The invaluable contribution of botanical gardens to biodiversity conservation and society can be further enhanced by collaborating with local $\mathrm{CH}$ groups by sharing resources and providing valuable training on the cultivation of IPs. Establishing extensive networks with local communities can induce ripple effects of the positive influence of botanical gardens in cultivating IPs across surrounding areas, and hence enhance their relevance to society at large.

\section{Conclusion}

Indigenous plants play important roles in certain $\mathrm{CH}$ initiatives, especially those that contribute to in situ, ex situ, and circa situ IP conservation, such as agroforestry, medicinal plant cultivation, ecosystem restoration, and urban greening/urban biodiversity conservation. Communal nurseries are key places for the cultivation of indigenous medicinal plants, as they may alleviate pressure on wild populations and increase the availability of rare and threatened species in order to meet market demands. Agroforestry systems are dependent on the diversity of tree species used, and indigenous trees offer a range of ecosystem goods and services to the local community while enriching wild populations and improving biodiversity conservation in agricultural landscapes. Key agroforestry projects involving medicinal tree cultivation in Africa demonstrate the powerful positive impacts on biodiversity conservation and local community socioeconomics. Indigenous plants will likely play an increasingly important role in providing food security, since they frequently offer superior alternatives to conventional non-native crops due to their high nutritional value and ability to grow in climatically harsh regions. It appears that IPs are more commonly planted in community gardens in rural areas than in cities, possibly because rural communities have more knowledge of and contact with the IPs in their surroundings and are therefore more likely to use them. The use of IPs for food security requires further research to unravel current trends and highlight opportunities for increased use. Native plant species can play pivotal roles in biodiversity conservation in urban landscapes, which have traditionally been ignored by conservationists focusing primarily on the preservation of 
"natural ecosystems." More research is needed on the benefits IPs offer in terms of reducing the routine maintenance of public gardens in cities, which often involves the use of irrigation and chemical pesticides, taking into account council needs and regulations. Biodiversity conservation in urban areas also goes hand in hand with ecosystem restoration, which is becoming increasingly important due to widespread habitat destruction across the globe, and offers yet another opportunity for the engagement of local communities in communal nurseries to supply IPs for restoration projects. Thus, the use of IPs in $\mathrm{CH}$, which is vital, but often under-recognized, deserves the attention of conservationists, researchers, local governments, non-governmental organizations, and citizens to devise and implement innovative solutions to socio-economic problems and biodiversity conservation worldwide. It is therefore recommended that community activists, policymakers, researchers, and non-governmental organizations engage in extensive networking and knowledge sharing so that the use of IPs can be integrated into more $\mathrm{CH}$ projects in the range of contexts in which they are found.

\section{References}

Akinnifesi, F. K., Kwesiga, F., Mhango, J., Chilanga, T., Mkonda, A., Kadu, C. A. C., ... Dhliwayo, P. (2006). Towards the development of miombo fruit trees as commercial tree crops in southern Africa. Forests, Trees and Livelihoods, $16,103-121$.

Aumeeruddy-Thomas, Y., Shinwari, Z. K., Ayaz, A., \& Khan, A. A. (2004). Ethnobotany and the management of fodder and fuelwood at Ayubia National Park, North West Frontier Province, Pakistan. People and plants working paper 13. Godalming, UK: WWF.

Böhringer, A., Ayuk, E. T., Katanga, R., \& Ruvuga, S. (2003). Farmer nurseries as a catalyst for developing sustainable land use systems in southern Africa. Part A: Nursery productivity and organization. Agricultural Systems, 77, 187-201.

Bolund, P., \& Hunhammar, S. (1999). Ecosystem services in urban areas. Ecological Economics, 29, 293-301.

Botha, J., Witkowski, E. T. F., \& Cock, J. (2006). The South African experience of conservation and social forestry outreach nurseries. Environmental Management, 38, 733-749.

Botha, J., Witkowski, E. T. F., \& Cock, J. (2007a). Is "something better than nothing"? The impacts of ten outreach nurseries on South African community stakeholders. Forests, Trees and Livelihoods, 17, 199-221. 
Botha, J., Witkowski, E. T. F., \& Cock, J. (2007b). Commercial viability of conservation and social forestry outreach nurseries in South Africa. Agroforestry Systems, 70, 135-156.

Botha, J., Witkowski, E. T. F., \& Shackleton, C. M. (2004). The impact of commercial harvesting on Warburgia salutaris ('pepper-bark tree') in Mpumalanga, South Africa. Biodiversity \& Conservation, 13(9), 1675-1698.

Botha, M. S., Carrick, P. J., \& Allsopp, N. (2008). Capturing lessons from landusers to aid the development of ecological restoration guidelines for lowland Namaqualand. Biological Conservation, 141, 885-895.

Breuste, J. H. (2004). Decision making, planning and design for the conservation of indigenous vegetation within urban development. Landscape and Urban Planning, 68, 439-452.

Buchmann, C., Prehsler, S., Hartl, A., \& Vogl, C. R. (2010). The importance of baobab (Adansonia digitata L.) in rural West African subsistence-suggestion of a cautionary approach to international market export of baobab fruits. Ecology of Food and Nutrition, 49(3), 145-172.

Buckingham, S. (2003). Allotments and community gardens: A DIY approach to environmental sustainability. In S. Buckingham, \& K. Theobald (Eds.), Local environmental sustainability (pp. 195-212). Cambridge: Woodhead Publishing.

Chalker-Scott, L., \& Collman, S. J. (2006). Washington State's Master Gardener Program: 30 years of leadership in university-sponsored, volunteercoordinated, sustainable CH. Journal of Cleaner Production, 14, 988-993.

Corrigan, M. P. (2011). Growing what you eat: Developing community gardens in Baltimore, Maryland. Applied Geography, 31, 1232-1241.

Cousins, S. R., Williams, V. L., \& Witkowski, E. T. F. (2011). Quantifying the trade in South African Encephalartos spp. in the traditional medicine markets of Johannesburg and Durban, South Africa. Economic Botany, 65(4), 356-370.

Cousins, S. R., Williams, V. L., \& Witkowski, E. T. F. (2012). Uncovering the cycad taxa (Encephalartos species) traded for traditional medicine in Johannesburg and Durban, South Africa. South African Journal of Botany, 78, 129-138.

Cruz-Garcia, P. S., \& Howard, P. L. (2013). "I used to be ashamed." The influence of an educational program on tribal and non-tribal children's knowledge and valuation of wild food plants. Learning and Individual Differences, 27, 234-240. 
Cunningham, A. B. (1994). Management of medicinal plant resources. In J. H. Seyani \& A. C. Chikuni (Eds.), Proceedings of the 13th plenary meeting of AETFAT, Zomba, Malawi, 2-11 April, 1991 (Vol. 1, pp. 173-189). National Herbarium and Botanic Gardens of Malawi, Zomba.

Cunningham, A. B. (2001). Return of the pepper-bark. Medicinal Plant Conservation, 7, 21-22.

Cunningham, A. B., Ayuk, E., Franzel, S., Duguma, B., \& Asanga, C. (2002). An economic evaluation of medicinal tree cultivation: Prunus africana in Cameroon. People and plants working paper 10. Paris: UNESCO.

de Neergaard, A., Drescher, A. W., \& Kouamé, C. (2009). Urban and periurban agriculture in African cities. In C. M. Shackleton, M. W. Pasquini \& A. W. Drescher (Eds.), African indigenous vegetables in urban agriculture (pp. 35-58). London: Earthscan.

Domene, E., \& Saurí, D. (2007). Urbanization and class-produced natures: Vegetable gardens in the Barcelona Metropolitan Region. Geoforum, 38(2), 287-298.

Donaldson, J. S. (2003). Cycads: A status survey and conservation action plan. Gland: IUCN/SSC Cycad Specialist Group.

Donaldson, J. S. (2009). Botanic gardens science for conservation and global change. Trends in Plant Science, 14(11), 608-613.

Dovie, D. B. K., Shackleton, C. M., \& Witkowski, E. T. F. (2007). Conceptualizing the human use of wild edible herbs for conservation in South African communal areas. Journal of Environmental Management, 84, 146-156.

Drake, L., \& Lawson, L. J. (2014). Validating verdancy or vacancy? The relationship of community gardens and vacant lands in the U.S. Cities, 40, 133-142.

Dreesen, D. R., \& Harrington, J. T. (1997). Propagation of native plants for restoration projects in the southwestern U.S.-Preliminary investigations. In T. D. Landis \& J. R. Thompson (Eds.), National proceedings: Forest and conservation nursery associations 1997 (General technical report PNWGTR-419, pp. 77-88). Portland OR: Forest Service, U.S. Department of Agriculture.

Dweba, T. P., \& Mearns, M. A. (2011). Conserving indigenous knowledge as the key to the current and future use of traditional vegetables. International Journal of Information Management, 31, 564-571. 
Dzerefos, C. M., \& Witkowski, E. T. F. (2001). Density and potential utilization of medicinal grassland plants from Abe Bailey Nature Reserve, South Africa. Biodiversity and Conservation, 10, 1875-1896.

FAO (Food and Agriculture Organization of the United Nations). (1995). Nonwood forest products for rural income and sustainable forestry (FAO Technical Report No. 7). Rome: Non-wood Forest Products Division, FAO.

Foster, J. (2009). From socio-nature to spectral presence: Re-imagining the once and future landscape of Johannesburg. Safundi: The Journal of South African and American Studies, 10(2), 175-213.

Gerstner, J. (1946). Some factors affecting perpetuation of our indigenous silva. Journal of the South African Forestry Association, 13, 4-11.

Goddard, M. A., Dougill, A. J., \& Benton, T. G. (2010). Scaling up from gardens: Biodiversity conservation in urban environments. Trends in Ecology and Evolution, 25(2), 90-98.

Grobler, C. H., Bredenkamp, G. J., \& Brown, L. R. (2006). Primary grassland communities of urban open spaces in Gauteng, South Africa. South African Journal of Botany, 72, 367-377.

Guitart, D. A., Pickering, C. A., \& Byrne, J. A. (2014). Color me healthy: Food diversity in school community gardens in two rapidly urbanising Australian cities. Health \& Place, 26, 110-117.

Hamilton, A. C. (2004). Medicinal plants, conservation and livelihoods. Biodiversity and Conservation, 13(8), 1477-1517.

Helm, C. V., Scott, S. L., \& Witkowski, E. T. F. (2011). Reproductive potential and seed fate of Sclerocarya birrea subsp. caffra (marula) in the low altitude savannas of South Africa. South African Journal of Botany, 77(3), 650-664.

Hynes, H. P., \& Howe, G. (2002). Urban horticulture in the contemporary United States: Personal and community benefits. Acta Horticulturae, 643, 171-181.

Iqbal, M. (1993). International trade in non-wood forest products: An overview. Rome: FAO.

Irvine, S., Johnson, L., \& Peters, K. (1999). Community gardens and sustainable land use planning: A case study of the Alex Wilson Community Garden. Local Environment, 4(1), 33-46.

Jäger, A. K., \& Van Staden, J. (2000). The need for cultivation of medicinal plants in southern Africa. Outlook on Agriculture, 29(4), 283-284. 
Jim, C. Y., \& Liu, H. T. (2001). Patterns and dynamics of urban forests in relation to land use and development history in Guangzhou City, China. The Geographical Journal, 167(4), 358-375.

Joffe, P. (2005). Creative gardening with indigenous plants: A South African guide. Pretoria: Briza Publications.

King, E. G. (2008). Facilitative effects of Aloe secundiflora shrubs in degraded semi-arid rangelands in Kenya. Journal of Arid Environments, 72, 358-369.

King, E. G., \& Stanton, M. L. (2008). Facilitative effects of Aloe shrubs on grass establishment, growth and reproduction in degraded Kenyan rangelands: Implications for restoration. Restoration Ecology, 16 (3), 464-474.

Koh, L. P., \& Gardner, T. A. (2010). Conservation in human-modified landscapes. In N. S. Sodhi \& P. R. Ehrlich (Eds.), Conservation biology for all (pp. 236261). Oxford: Oxford University Press.

Kowalski, B., \& van Staden, J. (2001). In vitro culture of two threatened South African medicinal trees-Ocotea bullata and Warburgia salutaris. Plant Growth Regulation, 34, 223-228.

Kuhnlein, H. V., \& Receveur, O. (1996). Dietary change and traditional food systems of indigenous people. Annual Review of Nutrition, 16, 417-442.

Kuzevanov, V., \& Sizykh, S. (2006). Botanic gardens resources: Tangible and intangible aspects of linking biodiversity and human well-being. Hiroshima Peace Science, 28, 113-134.

Lapido, D. O., Fondoun, J. M., \& Ganga, N. (1996). Domestication of the bush mango (Irvingia spp.): Some exploitable intraspecific variations in west and central Africa. In R. R. B. Leakey, A. B. Temu, M. Melnyk \& P. Vantomme (Eds.), Domestication and commercialisation of non-timber forest products in agroforestry systems (Non-Wood Forest Products 9, pp. 193-205). Rome: FAO.

Legwaila, G. M., Mojeremane, W., Madisa, M. E., Mmolotsi, R. M., \& Rampart, M. (2011). Potential of traditional food plants in rural household food security in Botswana. Journal of Horticulture and Forestry, 3(6), 171-177.

Long, A. J., \& Ramachandran Nair, P. K. (1999). Trees outside forests: Agro-, community and urban forestry. New Forests, 17, 145-174.

Loundou, P.-M. (2008). Medicinal plant trade and opportunities for sustainable management in the Cape Peninsula, South Africa (Unpublished master's thesis). University of Stellenbosch, Stellenbosch. 
Luoga, E. J., Witkowski, E. T. F., \& Balkwill, K. (2000). Differential utilization and ethnobotany of trees in Kitulanghalo Forest Reserve and surrounding communal lands, eastern Tanzania. Economic Botany, 54, 328-343.

Mander, L., Mander, J., \& Breen, C. (1996). Promoting the cultivation of indigenous plants for markets: Experiences from KwaZulu-Natal, South Africa. In R. R. B. Leakey, A. B. Temu, M. Melnyk \& P. Vantomme (Eds.), Domestication and commercialisation of non-timber forest products in agroforestry systems (Non-Wood Forest Products 9, pp. 104-109). Rome: FAO.

Markham, J., Young, I., \& Renault, S. (2011). Plant facilitation on a mine tailings dump. Restoration Ecology, 19(5), 569-571.

McKinney, M. L. (2002). Urbanization, biodiversity, and conservation. BioScience, 52(10), 883-890.

Munyanziza, E. (1996). Domestication of mushrooms from the miombo woodlands: Current status and crucial issues for agroforestry. In R. R. B. Leakey, A. B. Temu, M. Melnyk \& P. Vantomme (Eds.), Domestication and commercialisation of non-timber forest products in agroforestry systems (Non-Wood Forest Products 9, pp. 206-211). Rome: FAO.

Nair, C. T. S., \& Merry, F. D. (1995). Status of research on non-wood forest products: The Asia-Pacific situation. Report of the expert consultation on non-wood forest products, Yogyakarta, Indonesia, January 1995 (Non-Wood Forest Products 3, pp. 17-27). Rome: FAO.

Ndawonde, B. G., Zobolo, A. M., Dlamini, E. T., \& Siebert, S. J. (2007). A survey of plants sold by traders at Zululand muthi markets, with a view to selecting popular plant species for propagation in communal gardens. African Journal of Range and Forage Science, 24(2), 103-107.

Ngwira, T. N. (1996). Utilization of local fruit in wine making in Malawi. In R. R. B. Leakey, A. B. Temu, M. Melnyk \& P. Vantomme (Eds.), Domestication and commercialisation of non-timber forest products in agroforestry systems (Non-Wood Forest Products 9, pp. 188-191). Rome: FAO.

Ohlendorf, W. (1996). Domestication and crop development of Duboisia spp. (Solanaceae). In R. R. B. Leakey, A. B. Temu, M. Melnyk \& P. Vantomme (Eds.), Domestication and commercialisation of non-timber forest products in agroforestry systems (Non-Wood Forest Products 9, pp. 183-187). Rome: FAO.

Okafor, J. C. (1980). Edible indigenous woody plants in the rural economy of the Nigerian forest zone. Forest Ecology and Management, 3, 45-55. 
Parkin, F., Shackleton, C. M., \& Schudel, I. (2006). The effectiveness of schoolsbased National Arbor Week activities in greening of urban homesteads: A case study of Grahamstown, South Africa. Urban Forestry and Urban Greening, 5(4), 177-187.

Paumgarten, F., Shackleton, C. M., \& Cocks, M. (2005). Growing of trees in homegardens by rural households in the Eastern Cape and Limpopo provinces, South Africa. International Journal of Sustainable Development and World Ecology, 12, 365-383.

Pickett, S. T. A., \& Cadenasso, M. L. (2008). Linking ecological and built components or urban mosaics: An open cycle of ecological design. Journal of Ecology, 96, 8-12.

Pienaar, K. (1994). Gardening with indigenous plants. Struik Publishers.

Pollan, M. (1992). Afterword: The garden's prospects in America. In W. T. Punch (Ed.), Keeping Eden: A history of gardening in America. Boston, MA: Bulfinch Press.

Powell, M., Skowno, A., Mills, A., \& Knowles, T. (2004). Providing a context for the rehabilitation of subtropical thicket. In S. L. Wilson (Ed.), Proceedings of the 2004 thicket forum (Centre for African Conservation Ecology Report No. 54, pp. 57-60). Port Elizabeth: Nelson Mandela Metropolitan University.

Ranganathan, J., Daniels, R. J. R., Chandran, M. D. S., Ehrlich, P., \& Daily, G. C. (2008). Sustaining biodiversity in ancient tropical countryside. Proceedings of the National Academy of Sciences of the United States of America, 105, 17852-17854.

Relf, D. (1992). Human issues in horticulture. Horticultural Technology, 2(2), $159-171$.

Saldivar-Tanaka, L., \& Krasny, M. E. (2004). Culturing community development, neighborhood open space, and civic agriculture: The case of Latino community gardens in New York City. Agriculture and Human Values, 21, 399-412.

Saxena, K. G., Rao, K. S., Sen, K. K., Maikhuri, R. K., \& Semwal, R. L. (2001). Integrated natural resource management: Approaches and lessons from the Himalaya. Conservation Ecology, 5(2), 14. Retrieved from http://www. consecol.org/vol5/iss2/art14/ 
Schippmann, U., Cunningham, A. B., \& Leaman, D. J. (2003). Impact of cultivation and gathering of medicinal plants on biodiversity: Global trends and issues. In Biodiversity and the ecosystem approach in agriculture, forestry and fisheries: Proceedings (pp. 140-167). Rome: FAO.

Shackleton, C. M. (2002). Growth and fruit production of Sclerocarya birrea in the South African lowveld. Agroforestry Systems, 55, 175-180.

Shackleton, C. M., Pasquini, M. W., \& Drescher, A. W. (2009). African indigenous vegetables in urban agriculture. London: Earthscan.

Shah, V., \& Kalakoti, B. S. (1996). Development of Coleus forskahlii as a medicinal crop. In R. R. B. Leakey, A. B. Temu, M. Melnyk \& P. Vantomme (Eds.), Domestication and commercialisation of non-timber forest products in agroforestry systems (Non-Wood Forest Products 9, pp. 212-216). Rome: FAO.

Shimozono, F., \& Iwatsuki, K. (1986). Botanical gardens and the conservation of an endangered species in the Bonin Islands. Ambio, 15(1), 19-21.

Stuart Gager, C. (1919). Horticulture as a profession. Science, 49(1265), 293-300.

Troy, A. R., Grove, J. M., O'Neil-Dunne, J. P. M, Cadenasso, M. L., \& Pickett, S. T. A. (2007). Predicting opportunities for greening and patterns of vegetation on private urban lands. Environmental Management, 40, 394-412.

Tunnicliffe, S. D. (2001). Talking about plants - comments of primary school groups looking at plant exhibits in a botanical garden. Journal of Biological Education, 36(1), 27-34.

Uniyal, R. C., Uniyal, M. R., \& Jain, P. (2000). Cultivation of medicinal plants in India: A reference book. New Delhi: TRAFFIC India \& WWF India.

Venter, S. M., \& Witkowski, E. T. F. (2011). Baobab (Adansonia digitata L.) fruit production in communal and conservation land-use types in southern Africa. Forest Ecology and Management, 261, 630-639.

Venter, S. M., \& Witkowski, E. T. F. (2013). Fruits of our labour: Contribution of commercial baobab (Adansonia digitata L.) fruit harvesting to the livelihoods of marginalized people in northern Venda, South Africa. Agroforestry Systems, 87(1), 159-172.

Waliczek, T. M., Mattson, R. H., \& Zajicek, J. M. (1996). Benefits of community gardening on quality-of-life issues. Journal of Environmental Horticulture, 14(4), 204-209. 
Ward, C. D., Parker, C. M., \& Shackleton, C. M. (2010). The use and appreciation of botanical gardens as urban green spaces in South Africa. Urban Forestry \& Urban Greening, 9(1), 49-55.

Weiersbye, I. M., \& Witkowski, E. T. F. (2002). Seed fate and practical germination methods for 46 perennial species that colonize gold mine tailings and acid mine drainage-polluted soils in the grassland biome. In A. H. W. Seydack, T. Vorster, W. J. Vermeulen \& I. J. Van Der Merwe (Eds.), Multiple use management of natural forests and savanna woodlands: Policy refinements and scientific progress (pp. 221-255). Proceedings of Natural Forests \& Savanna Woodlands Symposium III, 6-9 May 2002, Berg-en-Dal, Kruger National Park.

Weiersbye, I. M., Witkowski, E. T. F., \& Reichardt, M. (2006). Floristic composition of gold and uranium tailings dams, and adjacent polluted areas, on South Africa's deep-level mines. Bothalia, 36(1), 101-127.

Wickens, G. E. (1991). Management issues for development of non-timber forest products. Unasylva, 42(165), 3-8.

Wiersum, K. F., Dold, A. P., Husselman, M., \& Cocks, M. (2006). Cultivation of medicinal plants as a tool for biodiversity conservation and poverty alleviation in the Amatola region, South Africa. In R. J. Bogers, L. E. Craker \& D. Lange (Eds.), Medicinal and aromatic plants: Agricultural, commercial, ecological, legal, pharmacological and social aspects (Wageningen UR Frontis Series Vol. 17, pp. 43-57). Dordrecht: Springer.

Williams, V. L., Balkwill, K., \& Witkowski, E. T. F. (2000). Unravelling the market for commercial medicinal plants and plant parts on the Witwatersrand, South Africa. Economic Botany, 54(3), 310-327.

Xaba, P. (2007). Africa's miracle bean, the cowpea. Veld \& Flora, 93(3), 168-170. 
This text taken from Human Ecology Review Volume 21, Number 1, 2015, published 2015 by ANU Press, The Australian National University, Canberra, Australia. 